\title{
Shoreline Dynamics in East Java Province, Indonesia, from 2000 to 2019 Using Multi-Sensor Remote Sensing Data
}

\author{
Sanjiwana Arjasakusuma ${ }^{1, * D}$, Sandiaga Swahyu Kusuma ${ }^{1}$, Siti Saringatin ${ }^{1}$, Pramaditya Wicaksono ${ }^{1}$ (D), \\ Bachtiar Wahyu Mutaqin ${ }^{2}$ (D) and Raihan Rafif ${ }^{1}$
}

1 Department of Geographic Information Science, Faculty of Geography, Gadjah Mada University, Bulaksumur, Yogyakarta 55281, Indonesia; sandiaga.kusuma@mail.ugm.ac.id (S.S.K.); siti.saringatin@mail.ugm.ac.id (S.S.); prama.wicaksono@ugm.ac.id (P.W.); raihanrafif@mail.ugm.ac.id (R.R.)

2 Department of Environmental Geography, Faculty of Geography, Gadjah Mada University, Bulaksumur, Yogyakarta 55281, Indonesia; mutaqin@ugm.ac.id

* Correspondence: sanjiwana.arjasakusuma@ugm.ac.id

Citation: Arjasakusuma, S.; Kusuma, S.S.; Saringatin, S.; Wicaksono, P.; Mutaqin, B.W.; Rafif, R. Shoreline Dynamics in East Java Province, Indonesia, from 2000 to 2019 Using Multi-Sensor Remote Sensing Data. Land 2021, 10, 100. https://doi.org/ 10.3390/land 10020100

Received: 9 December 2020

Accepted: 19 January 2021

Published: 22 January 202

Publisher's Note: MDPI stays neutral with regard to jurisdictional claims in published maps and institutional affiliations.

Copyright: (c) 2021 by the authors. Licensee MDPI, Basel, Switzerland. This article is an open access article distributed under the terms and conditions of the Creative Commons Attribution (CC BY) license (https:// creativecommons.org/licenses/by/ $4.0 /)$.

\begin{abstract}
Coastal regions are one of the most vulnerable areas to the effects of global warming, which is accompanied by an increase in mean sea level and changing shoreline configurations. In Indonesia, the socioeconomic importance of coastal regions where the most populated cities are located is high. However, shoreline changes in Indonesia are relatively understudied. In particular, detailed monitoring with remote sensing data is lacking despite the abundance of datasets and the availability of easily accessible cloud computing platforms such as the Google Earth Engine that are able to perform multi-temporal and multi-sensor mapping. Our study aimed to assess shoreline changes in East Java Province Indonesia from 2000 to 2019 using variables derived from a multi-sensor combination of optical remote sensing data (Landsat-7 ETM and Landsat-8 OLI) and radar data (ALOS Palsar and Sentinel-1 data). Random forest and GMO maximum entropy (GMO-Maxent) accuracy was assessed for the classification of land and water, and the land polygons from the best algorithm were used for deriving shorelines. In addition, shoreline changes were quantified using Digital Shoreline Analysis System (DSAS). Our results showed that coastal accretion is more profound than coastal erosion in East Java Province with average rates of change of +4.12 (end point rate, EPR) and $+4.26 \mathrm{~m}$ /year (weighted linear rate, WLR) from 2000 to 2019. In addition, some parts of the shorelines in the study area experienced massive changes, especially in the deltas of the Bengawan Solo and Brantas/Porong river with rates of change (EPR) between -87.44 to +89.65 and -18.98 to $+111.75 \mathrm{~m} /$ year, respectively. In the study areas, coastal erosion happened mostly in the mangrove and aquaculture areas, while the accreted areas were used mostly as aquaculture and mangrove areas. The massive shoreline changes in this area require better monitoring to mitigate the potential risks of coastal erosion and to better manage coastal sedimentation.
\end{abstract}

Keywords: remote sensing; maximum entropy; Landsat; ALOS Palsar; Sentinel-1; Google Earth Engine

\section{Introduction}

Global warming caused by increasing greenhouse gas abundance in the atmosphere is projected to result in an average sea level rise of 20 to $200 \mathrm{~cm}$ in the 21st century [1], and the sea level in the year 2100 is projected to be $310 \pm 30 \mathrm{~mm}$ higher than that in 1990 [2]. The sea level rise induced by global warming is thought to be accelerated by the contribution of ice sheet melting in Greenland and Antarctica [3-5]. The increase in sea level has the potential to affect shorelines [6] and thus to amplify coastal erosion [7-10]. In addition, global warming increases the risk of extreme weather by strengthening the thermodynamic factors for generating tropical cyclone and storm surges, which subsequently increases the risk of coastal flooding and coastal erosion due to the elevated surge height from the intensifying winds, waves, and atmospheric pressures [11-14]. These climate-changeinduced events could potentially affect communities living near coasts, meaning that global 
and regional monitoring efforts should be conducted to mitigate future problems $[7,15]$. These efforts are especially relevant in regions of South, Southeast, and East Asia, where the most populated cities are located in coastal areas [4] and where human activities such as groundwater usage could trigger coastal lowland subsidence, adding to the risk of hazards in coastal areas [16].

Despite ongoing sea level rise, coastal lowland subsidence and erosion, and enhanced storminess, the expansion of urban settlements into coastal areas still continues [15]. These coastal areas include low coastal plains, deltas, and small islands, all of which are susceptible to sea level rise and coastal erosion $[17,18]$. In South, Southeast, and East Asia, many deltas are the sites of rapidly growing cities with dense populations [4]. In Indonesia, particularly on Java Island, densely populated coastal megacities such as Jakarta, Semarang, and Surabaya are prone to environmental hazards, including coastal erosion and seawater tides $[19,20]$. These cities, besides being characterized by rapidly increasing populations, are also regarded as centers of economic activity, having gross regional domestic product (GRDP) increases of more than 5\% per year in the period from 2000 to 2004 [21]. To overcome these problems, several options for coastal defense, ranging from artificial structures such as conventional engineering structures (e.g., sea walls) to natural protections (e.g., reefs) and beach nourishment, are available, with natural defense structures offering more sustainable and environmentally friendly coastal protection $[13,22,23]$. The broader context of coastal protection was formulated as integrated coastal management, which offered a holistic approach by involving all the stakeholders and policy makers and considering the socioeconomic and environmental aspects [24,25].

Considering the socioeconomic and ecological importance of coastal areas in Indonesia, it is imperative to understand the dynamics of these coastal areas to identify the possible socioeconomic impacts. Several local monitoring efforts have been conducted in Semarang [26], Jakarta [27], Bantul [10], Surabaya and Gresik [28,29], and the northern coastline of Java Island [30]. However, regional monitoring efforts in Indonesia are still needed to be able to identify the shoreline dynamics across larger areas and over longer temporal scales. This can be achieved by utilizing the abundance of available remote sensing data and cloud computing platforms.

Efforts to monitor shoreline dynamics have been supported by the availability of multi-temporal remote sensing data. Blodget et al. [31], for instance, employed $80 \mathrm{~m}$ spatial resolution Landsat MSS data to estimate coastal accretion and erosion in the Nile Delta of Egypt from 1972 to 1987 . Other studies have also benefited from the archive of Landsat and/or SPOT data for monitoring shoreline changes in various locations, such as the Mediterranean coast of Turkey [32], Bandar Abbas [33], and Vietnam [34], through the use of various methods, including manual digitization, threshold methods [34], and soft or hard pixel classification $[30,35]$. These studies illustrate the potential of satellite data in monitoring areas experiencing massive changes due to land accretion and erosion.

The availability of cloud computing platforms, such as the Google Earth Engine (GEE) [36], has enabled the upscaling of shoreline change monitoring to the regional scale through the use of their remote sensing data archives, which allow for the selection of cloud- and wave-free imagery beneficial for analyzing shoreline changes. For instance, Landsat data from 1985 to 2018 and nighttime data from the Defense Meteorological Satellite Program's Operational Linescan System (DMSP-OLS) in the GEE platform were used to explore the relationship between shoreline changes and human activities [37], while other researchers employed the Landsat and Sentinel-2 data archive in the GEE to develop CoastSat, a tool for the automation of time-series shoreline mapping [38]. Both studies demonstrate the applicability of the GEE to multi-temporal shoreline monitoring using remote sensing data, with which cloud- and wave-free imagery can be obtained from the composite of the archive data, increasing the accuracy of shoreline derivation [38].

Pressures from industrial activities in Gresik and the coastal megacity of Surabaya, along with degraded river systems, have become a problem in East Java Province. The 
shoreline changes in this area are also relatively understudied because of a lack of big datasets necessary for regional-level mapping. Therefore, our study aimed to

1. Implement the cloud computing platform of the Google Earth Engine and its accompanying remote sensing datasets (i.e., Landsat-5 TM, Landsat-7 ETM, Landsat-8 OLI, and Sentinel-1) to perform a regional mapping of the shoreline dynamics in a part of East Java Province;

2. Monitor the regional shoreline dynamics and the affected land use in a part of the eastern coastal areas of East Java Province from 2000 to 2019 at 4- to 5-year intervals.

\section{Materials and Methods}

\subsection{Study Area}

The study took place in the eastern coastal region of East Java Province, Indonesia, between 112.45 to $114.21^{\circ} \mathrm{E}$ and 6.833 to $7.93^{\circ} \mathrm{S}$ (Figure 1). East Java Province was chosen as the study area because of the presence of Surabaya, a coastal megacity, and the industrial development of the coastal regions. This is compounded by the degradation of the watersheds of the main rivers in East Java (i.e., Brantas/Porong and Bengawan Solo), which has increased organic sediment load [39] and domestic plastic pollution [40,41] due to improper waste management, both of which affect the marine environment [42].

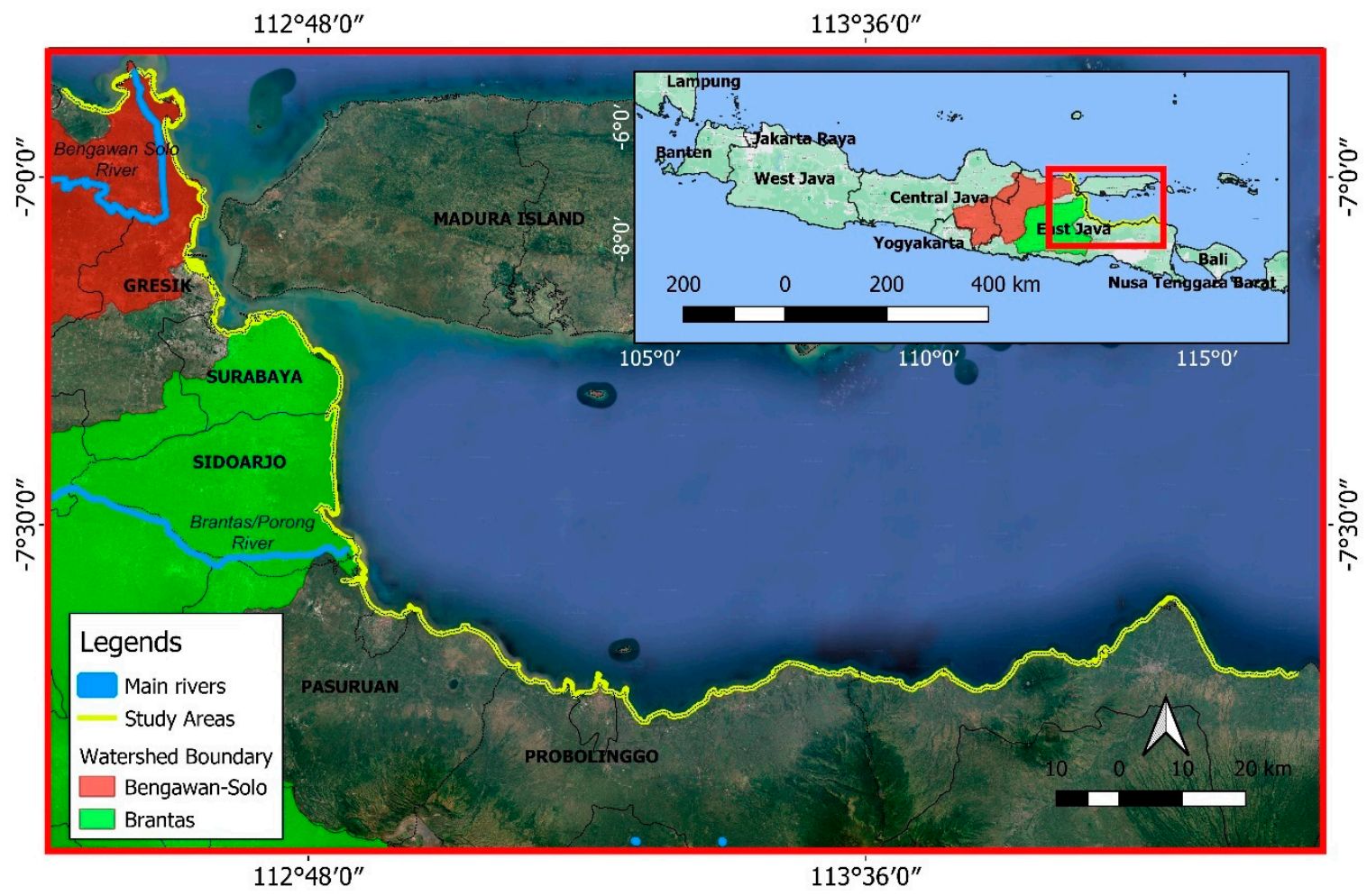

Figure 1. The study area (yellow line), comprising the coastline of the main island of Java Island, Indonesia.

\subsection{Data}

This study used Landsat surface reflectance data with a $30 \mathrm{~m}$ spatial resolution as the main datasets, which were accessed and processed in the GEE for the years 2000, 2005, 2010, 2015, and 2019 by taking the median reflectance values within each year. Depending on availability, some years (i.e., 2010, 2015, and 2019) included SAR data from ALOS Palsar/Global Palsar (horizontal-horizontal, HH, and horizontal-vertical, HV, polarizations at a $25 \mathrm{~m}$ spatial resolution) and Sentinel-1 C-band data (vertical-vertical, $\mathrm{VV}$, and vertical-horizontal, $\mathrm{VH}$, polarizations at a $10 \mathrm{~m}$ spatial resolution) to complement the Landsat surface reflectance (SR) data in the GEE. All radar data were resampled to a 
$30 \mathrm{~m}$ spatial resolution to match the resolution of the Landsat data. The combination of SAR backscatter and spectral bands from optical data is thought to increase the accuracy of land-use and land-cover classification, as reported in studies on classifying land cover in Southeast Asia [43], identifying flooded wetland areas [44], and enhancing the accuracy of shoreline mapping [45].

Several spectral indices from the Landsat data were generated as additional variables, besides the spectral bands, for the input analysis. Several indices were used, such as the normalized difference water index (NDWI) [46] (Equation (1)), the normalized difference vegetation index (NDVI) [47] (Equation (2)), and the non-shadow version (AWEInsh) of the automated water extraction index (AWEI) [48] (Equation (3)). The non-shadow version was used because of the relatively clear shadow pixels (i.e., cloud or dark surfaces) in the study areas. The equations for these indices are provided below.

$$
\begin{gathered}
\text { NDWI }=\frac{\text { Green }- \text { NIR }}{\text { Green }+ \text { NIR }} \\
N D V I=\frac{\text { NIR }- \text { Red }}{\text { NIR }+ \text { Red }} \\
\text { AWEInsh }=\text { Blue }+2.5 \times \text { Green }-1.5 \times(\text { NIR }+ \text { SWIR } 1)-0.25 \times \text { SWIR } 2
\end{gathered}
$$

where blue, green, red, near infrared (NIR), shortwave infrared 1 (SWIR1), and shortwave infrared 2 (SWIR2) represent the spectra of the optical bands of the Landsat data. The complete list of variables used for classification can be found in Table 1.

Table 1. Variables from remote sensing data used for classification.

\begin{tabular}{ccc}
\hline Year of Analysis & Sensors & Input Band \\
\hline \multirow{2}{*}{2000} & Landsat-7 ETM+ (SR) & $\begin{array}{c}\text { red, green, blue, NIR, SWIR1, SWIR2 } \\
\text { NDWI, NDVI, AWEInsh }\end{array}$ \\
\hline \multirow{2}{*}{2005} & Landsat-7 ETM+ (SR) & $\begin{array}{c}\text { red, green, blue, NIR, SWIR1, SWIR2 } \\
\text { NDWI, NDVI, AWEInsh }\end{array}$ \\
\hline \multirow{2}{*}{2010} & Landsat-7 ETM+ (SR) & $\begin{array}{c}\text { red, green, blue, NIR, SWIR1, SWIR2 } \\
\text { NDWI, NDVI, AWEInsh }\end{array}$ \\
\cline { 2 - 3 } & Alos PALSAR/Global Palsar & HH, HV \\
\hline \multirow{2}{*}{2015} & Landsat-8 OLI (T1_SR) & $\begin{array}{c}\text { red, green, blue, NIR, SWIR1, SWIR2 } \\
\text { NDWI, NDVI, AWEInsh }\end{array}$ \\
\cline { 2 - 3 } & Sentinel-1 Descending Orbit & VV, VH \\
\hline \multirow{2}{*}{2019} & Landsat-8 OLI (T1_SR) & red, green, blue, NIR, SWIR1, SWIR2 \\
& NDWI, NDVI, AWEInsh \\
\cline { 2 - 3 } & Sentinel-1 Descending Orbit & VV, VH \\
\hline
\end{tabular}

\subsection{Supervised Classification}

The supervised classification in this study was performed using GMO maximum entropy (GMO-Maxent) in the GEE [49]. GMO-Maxent is a multinomial logistic regression model for multi-class classification that is less computationally intensive than the standard optimization of the conditional maximum entropy (Maxent) model for deriving the probability distribution. The GMO-Maxent algorithm is rooted in the concept of entropy or amount of information stored within a variable [50,51]. The entropy was calculated from the sum of the occurrence probabilities of the variables $p(i)$ multiplied by the surprise element or the binary logarithm $\left(\log _{2} p(i)\right)$ of the variable $i$. Therefore, Shannon's entropy $(E)$ can be summarized as Equation (4):

$$
E=-\sum_{i}\left(p(i) \times \log _{2}(p(i))\right.
$$


The concept of Shannon's entropy was brought into its modern form, usually known as the maximum entropy principle, by Jaynes [52]. This form was developed to deal with the unknown estimation of the probabilities of an event $p(i)$ by using the probability distribution of the maximum entropy from a known event, as in statistical mechanics. The maximum entropy probability distribution can be viewed as the most uniform and spread-out distribution that can satisfy any given constraint to represent the target distribution $[53,54]$.

This algorithm is rarely used for the classification of remote sensing data [55], especially for multi-class classification. However, it is a well-known method in studies of species distributions and habitat models [53,56,57], and it has been reported to perform better in one-class or binary classification applications than other algorithms, such as the support vector machine method [58]. The GMO-Maxent method was compared with the random forest (RF) method [59] in classifying land, suspended sediment, and seawater body classes. To assess the accuracy of both methods, we randomly distributed 500 points, both on land and non-land bodies, along $1 \mathrm{~km}$ of the detected shoreline and constructed a confusion matrix to calculate the producer's accuracy (PA), user's accuracy (UA), and overall accuracy (OA) (Figure 2).
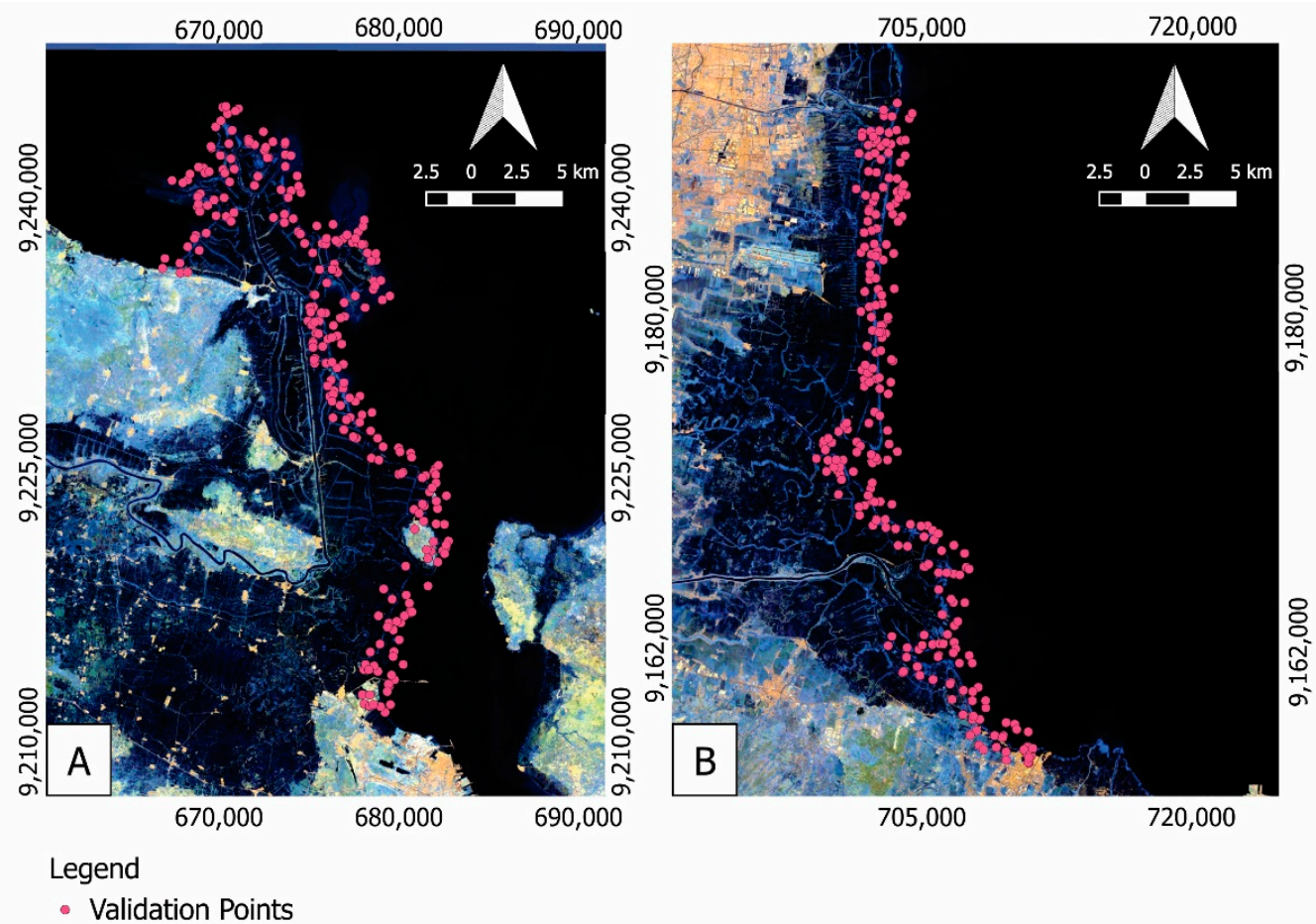

- Validation Points

Figure 2. Randomly distributed sample points along the $1 \mathrm{~km}$ buffer areas of the (A) Gresik and (B) Sidoarjo shorelines, used in the accuracy assessment of the GMO maximum entropy (GMO-Maxent) and random forest (RF) methods.

In addition to the land and seawater classification, additional supervised classification with RFs was used to identify the affected areas and the type of land use in 2000 to 2019 from the results of coastal erosion and accretion. Two areas with major changes were identified from the shoreline analysis, and supervised classification was conducted. The following classes were identified from the imagery: (1) aquaculture, (2) mangrove, (3) agricultural, (4) built-up, and (5) bare land areas.

\subsection{Shoreline Refinement and Change Assessment}

The land polygons of each classified map from 2000 to 2019 were used to represent the shorelines and to quantify shoreline changes. After selecting the best results from the classification and before quantifying the shoreline changes, visual and manual refinement were conducted by identifying any misclassifications that overshot or undershot 
land/water boundaries and by editing the vector vertices to better represent the border of land areas. This refinement was conducted to ensure that the calculations would most accurately reflect the shoreline changes.

To estimate the rate of shoreline changes, the ArcGIS plugin of Digital Shoreline Analysis System (DSAS) version 5.0 [60] was used. This plugin has been employed in various studies to calculate shoreline changes. It provides various statistical analyses, including linear regression rate (LRR), end point rate (EPR), and weighted linear regression (WLR) [61,62], as well as net shoreline movement (NSM) and shoreline change envelope (SCE) estimation [60]. EPR provides the rate of change based on the distance difference between the shoreline position in the baseline year and the end year, while WLR provides the best-fitted line for the linear rate of change by considering the uncertainty value [32]. EPR can yield a negative value, which represents coastal erosion, and a positive value, which represents coastal accretion. DSAS provides the capability for detailed and systematic calculation of the shoreline change rate by automatically generating transect lines perpendicular to a baseline $[10,60]$. The statistical analysis in DSAS was carried out by placing the transect lines along the shoreline, with the starting points of the transect lines being determined by the baseline. The baseline that we used in this study was the shoreline in the year 2000. In addition, we defined the following parameters for DSAS: a transect spacing of $50 \mathrm{~m}$ and a maximum search distance of $2 \mathrm{~km}$.

A summary of the analysis workflow is presented in Figure 3. The GEE code for conducting the analysis is provided in the Supplementary Materials.
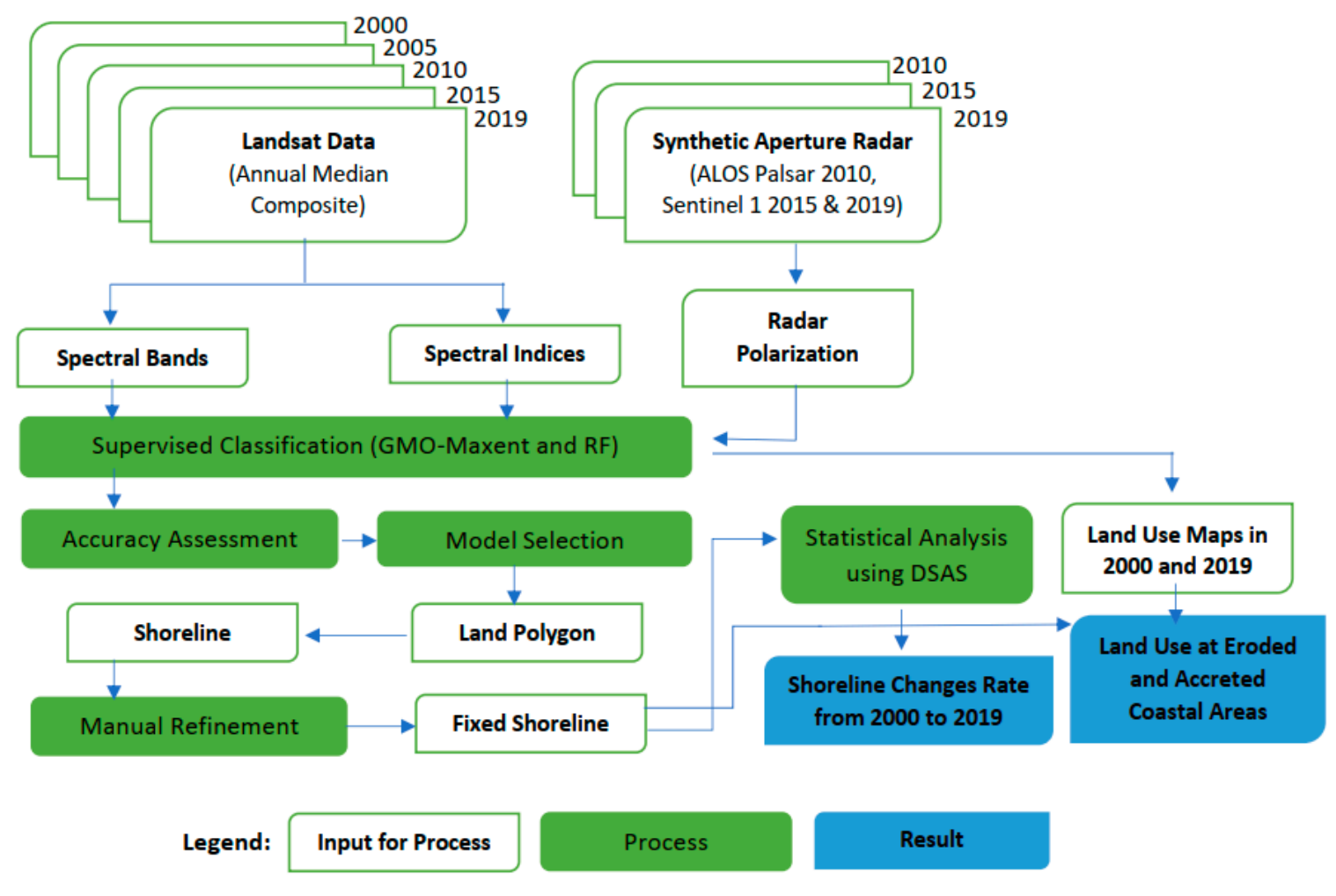

Figure 3. Study methodology flowchart.

\section{Results}

\subsection{Accuracy Assessment}

The accuracy assessment of RFs and GMO-Maxent showed that GMO-Maxent performed best in separating land and water body classes. Table 2 shows the results of the accuracy assessment for the years 2000, 2005, 2010, 2015, and 2019. From the table, it can be seen that GMO-Maxent yielded the higher overall accuracies, especially for the classifications in 2000, 2005, and 2010, while RFs yielded better accuracy for the years 2015 and 2019. 
The better accuracy of RFs in 2015 and 2019 can be attributed to the use of Landsat- 8 and Sentinel-1 data in the classification inputs, which helped to increase the accuracy of the RF algorithm. However, the other multi-sensor combination of Landsat-7 ETM and Global PALSAR-2 yearly mosaic data in 2010 did not yield the same results, with the accuracy of the RF models still falling below that of the GMO-Maxent models. It should be noted that Landsat-7 ETM in 2010 suffered from a scan-line error, rendering missing values on several lines in the imagery, which were filled by annual median values, but this was still imperfect, with noticeable changes in the spectral values of the surrounding pixels. It seems that the RF method was affected more by this artifact than the GMO-Maxent model.

Table 2. Summary of the accuracy assessment results (in percentage) of the RF and GMO-Maxent methods.

\begin{tabular}{|c|c|c|c|c|c|c|c|c|c|}
\hline \multicolumn{10}{|c|}{2000} \\
\hline \multirow{2}{*}{ Class } & \multicolumn{3}{|c|}{ RF (ntree: 50) } & \multicolumn{3}{|c|}{ RF (ntree: 80) } & \multicolumn{3}{|c|}{ GMO-Maxent } \\
\hline & UA & $\mathrm{PA}$ & $\mathrm{OA}$ & UA & $\mathrm{PA}$ & $\mathrm{OA}$ & UA & PA & $\mathrm{OA}$ \\
\hline Land & 78.36 & 94.47 & \multirow{2}{*}{84} & 78.18 & 94.86 & \multirow{2}{*}{84} & 92.34 & 95.26 & \multirow{2}{*}{93.6} \\
\hline Water & 92.82 & 73.28 & & 93.26 & 72.87 & & 94.98 & 91.90 & \\
\hline \multicolumn{10}{|c|}{2005} \\
\hline \multirow{2}{*}{ Class } & \multicolumn{3}{|c|}{ RF (ntree: 50) } & \multicolumn{3}{|c|}{ RF (ntree: 80) } & \multicolumn{3}{|c|}{ GMO-Maxent } \\
\hline & UA & PA & $\mathrm{OA}$ & UA & PA & $\mathrm{OA}$ & UA & PA & $\mathrm{OA}$ \\
\hline Land & 81.50 & 94.54 & \multirow{2}{*}{84.6} & 80.61 & 89.08 & \multirow{2}{*}{84.4} & 86.54 & 94.54 & \multirow{2}{*}{90.4} \\
\hline Water & 87.40 & 86.64 & & 89.03 & 80.53 & & 94.58 & 86.64 & \\
\hline \multicolumn{10}{|c|}{2010} \\
\hline \multirow{2}{*}{ Class } & \multicolumn{3}{|c|}{ RF (ntree: 50) } & \multicolumn{3}{|c|}{ RF (ntree: 80) } & \multicolumn{3}{|c|}{ GMO-Maxent } \\
\hline & UA & PA & $\mathrm{OA}$ & UA & PA & OA & UA & PA & OA \\
\hline Land & 93.65 & 90.42 & \multirow{2}{*}{91.8} & 93.68 & 90.80 & \multirow{2}{*}{92} & 98.77 & 91.95 & \multirow{2}{*}{95.2} \\
\hline Water & 89.92 & 93.31 & & 90.28 & 93.31 & & 91.83 & 98.74 & \\
\hline \multicolumn{10}{|c|}{2015} \\
\hline \multirow{2}{*}{ Class } & \multicolumn{3}{|c|}{ RF (ntree: 50) } & \multicolumn{3}{|c|}{ RF (ntree: 80) } & \multicolumn{3}{|c|}{ GMO-Maxent } \\
\hline & UA & PA & $\mathrm{OA}$ & UA & PA & OA & UA & PA & $\mathrm{OA}$ \\
\hline Land & 90.23 & 89.19 & \multirow{2}{*}{89.4} & 88.68 & 90.73 & \multirow{2}{*}{89.2} & 84.67 & 85.33 & \multirow{2}{*}{84} \\
\hline Water & 88.52 & 89.63 & & 89.79 & 87.55 & & 84.68 & 82.57 & \\
\hline & & & & & & & & & \\
\hline Class & & (ntree: & & & (ntree: & & & IO-Max & \\
\hline & UA & PA & $\mathrm{OA}$ & UA & PA & $\mathrm{OA}$ & UA & PA & $\mathrm{OA}$ \\
\hline Land & 91.53 & 91.14 & 918 & 92.27 & 90.72 & 92 & 90.12 & 92.41 & 916 \\
\hline Water & 92.05 & 92.40 & & 91.76 & 93.16 & & 93.36 & 90.87 & \\
\hline
\end{tabular}

For the years 2000 and 2005, the RF algorithms yielded $6 \%$ to $9.6 \%$ lower overall accuracies than GMO-Maxent. The low accuracies of the RF method for these years resulted from the large number of false positives (commission errors), as evidenced by the fact that the user's accuracies were lower than the producer's accuracies in the land class. These errors can be attributed largely to the presence of fishponds in some parts of the study area, which were classified as bodies of water and thus affected the shoreline results. Therefore, if the RF results were used, it would require laborious refinements to be able to accurately estimate the shoreline changes for those areas (Figure $4 a, b)$. In conclusion, the shoreline change analysis was ultimately conducted using the results of the GMO-Maxent 
method, which yielded a more stable classification with relatively few errors, thus reducing the need for manual refinement.
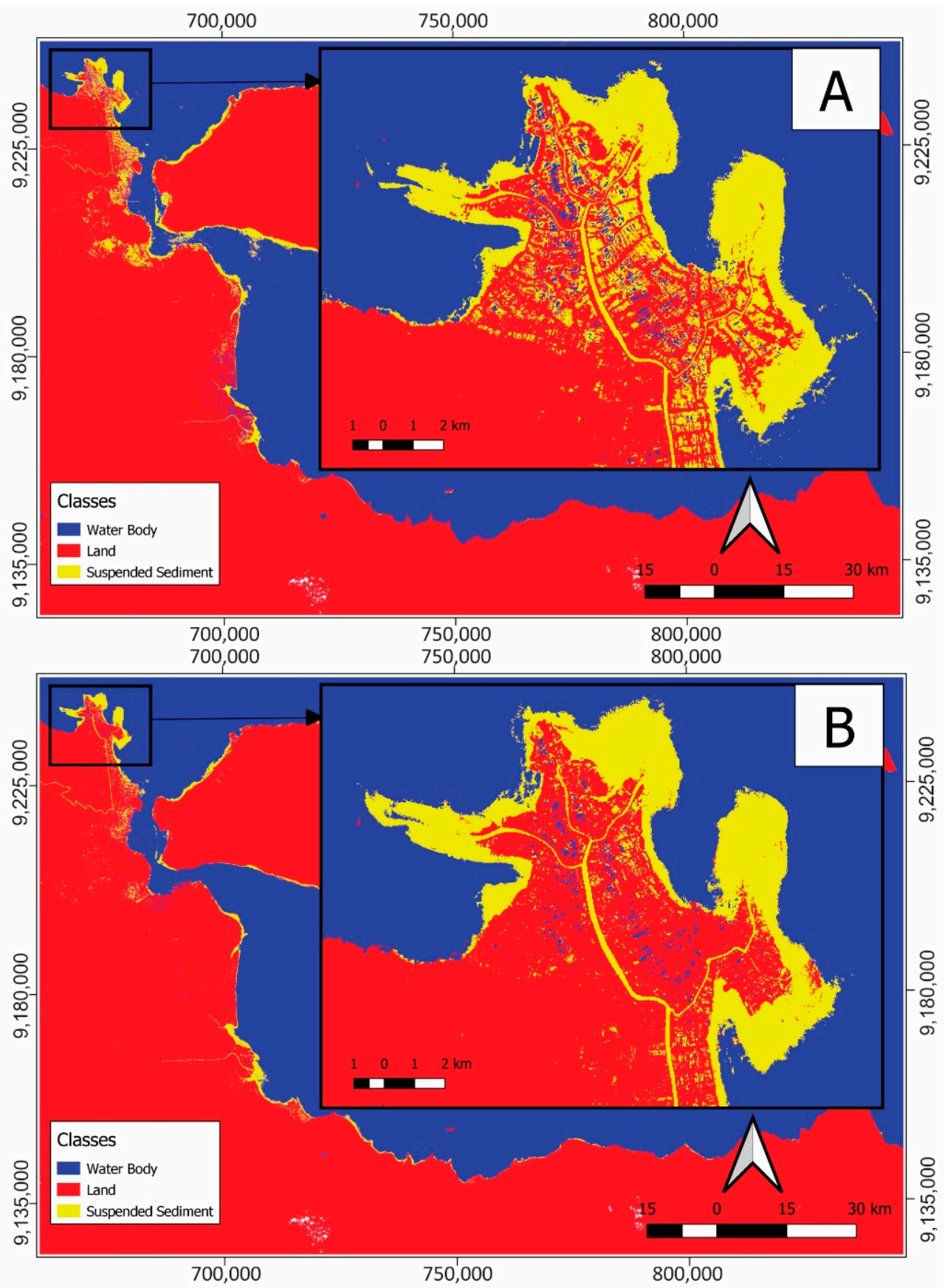

Figure 4. Classification of land and water bodies (seawater in blue, turbid water in yellow) in the year 2000 by (A) RF with 80 trees (OA: 84\%) and (B) GMO-Maxent (OA: 93.6\%), revealing the misclassification of land areas as turbid water (inset).

\subsection{Shoreline Changes from 2000 to 2019}

The shorelines in 2000, 2005, 2010, 2015, and 2019 detected from the land polygons by the GMO-Maxent algorithm were refined and analyzed using DSAS, which placed 7817 transect lines along the shoreline. Based on the distributed transect lines from DSAS (Figure 5), we found an average EPR of $4.12 \mathrm{~m} /$ year and an average WLR of $4.26 \mathrm{~m} /$ year. Although the statistics of average EPR and WLR indicated overall coastal accretion, we identified regions of both major erosion and major accretion (Figure 6A) in the northwest- 
ern part of East Java Province, which represents the delta of the Bengawan Solo river (Figure 6A), and coastal accretion, which represents the delta of the Brantas/Porong river (Figure 6B).

\section{Rate of Change from EPR and WLR Analysis in DSAS}

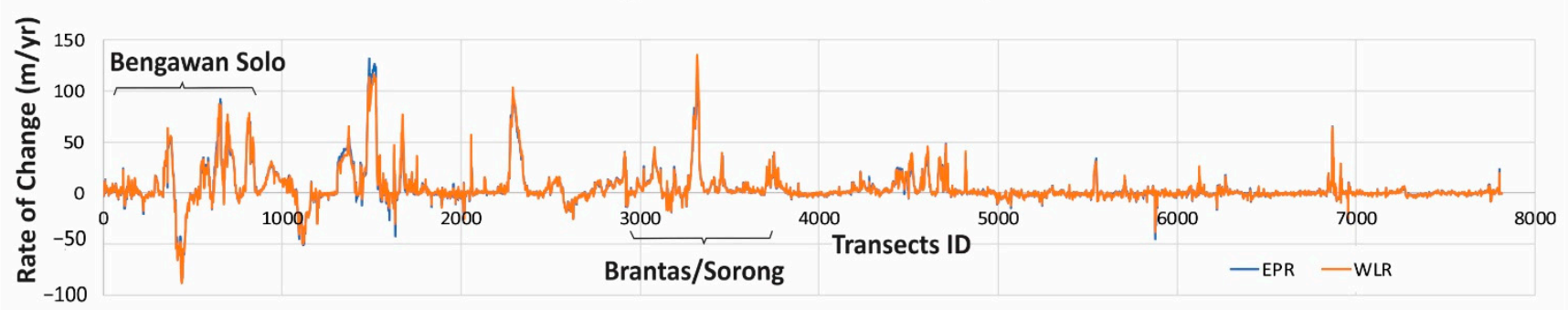

Figure 5. End point rate (EPR) and weighted linear regression rate (WLR) statistics from the transect lines, revealing major regions of shoreline changes along the shoreline of East Java.
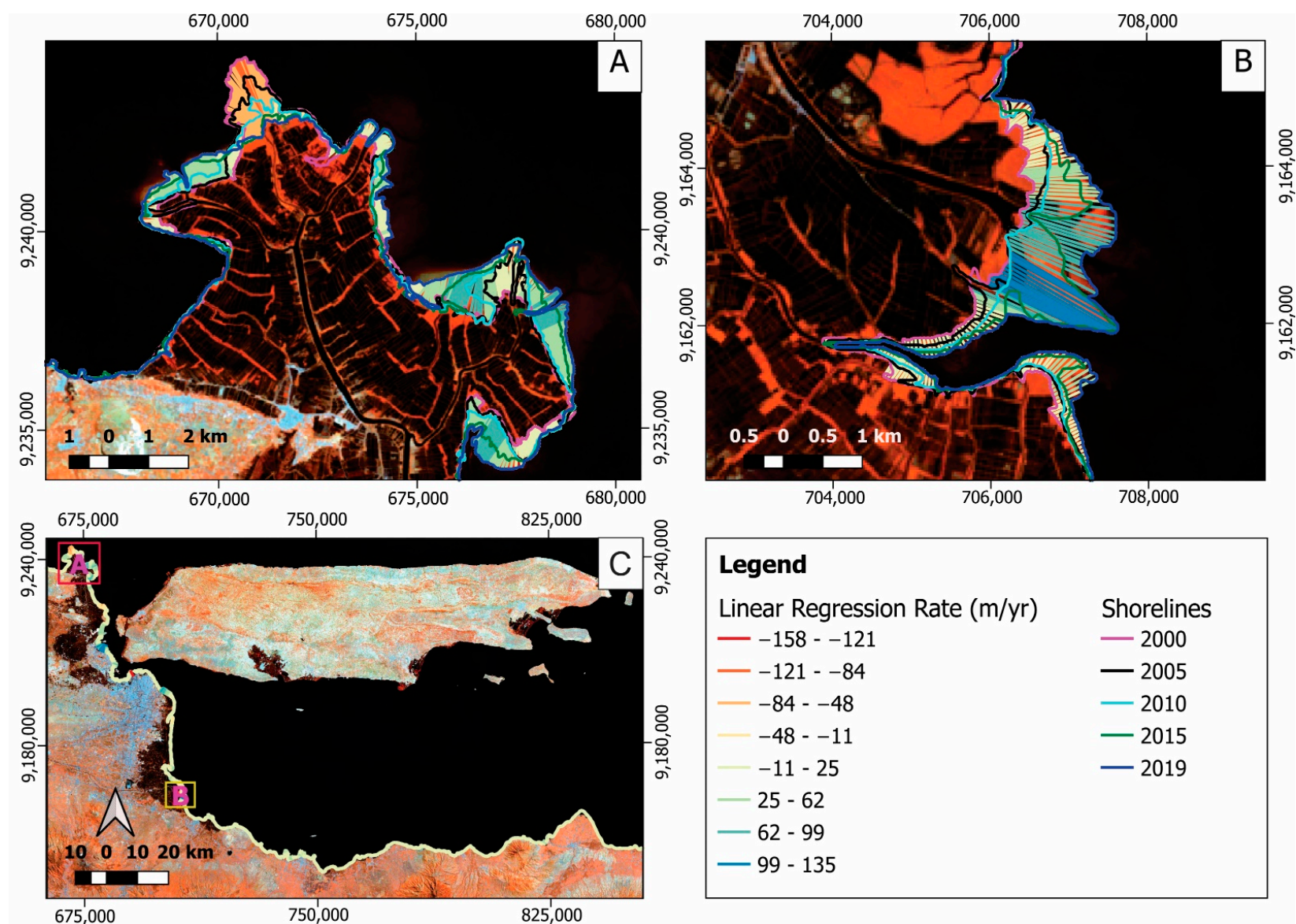

Figure 6. Major shoreline changes in (A) the Bengawan Solo delta, which experienced major erosion and accretion, and (B) the Brantas/Porong delta, which experienced major accretion, with Inset (C) showing the location of both deltas on the shoreline of East Java province.

Two regions - the deltas of Bengawan Solo (Figure 6A) and Brantas/Porong (Figure 6B) —experienced major shoreline changes from 2000 to 2019. In the Bengawan Solo delta, the average movement of the shoreline derived from the transect lines was approximately $+10.2 \mathrm{~m} /$ year, with some areas experiencing accretion rates of up to $89.65 \mathrm{~m} /$ year and others experiencing erosion rates of up to $-87.44 \mathrm{~m} /$ year (Figure 7 ). These results, while 
indicating the overall dominance of sedimentation in the area, also point to the delta's highly dynamic nature. The land covering this delta is dominated by aquaculture ponds, in addition to vegetation in the riparian zone.

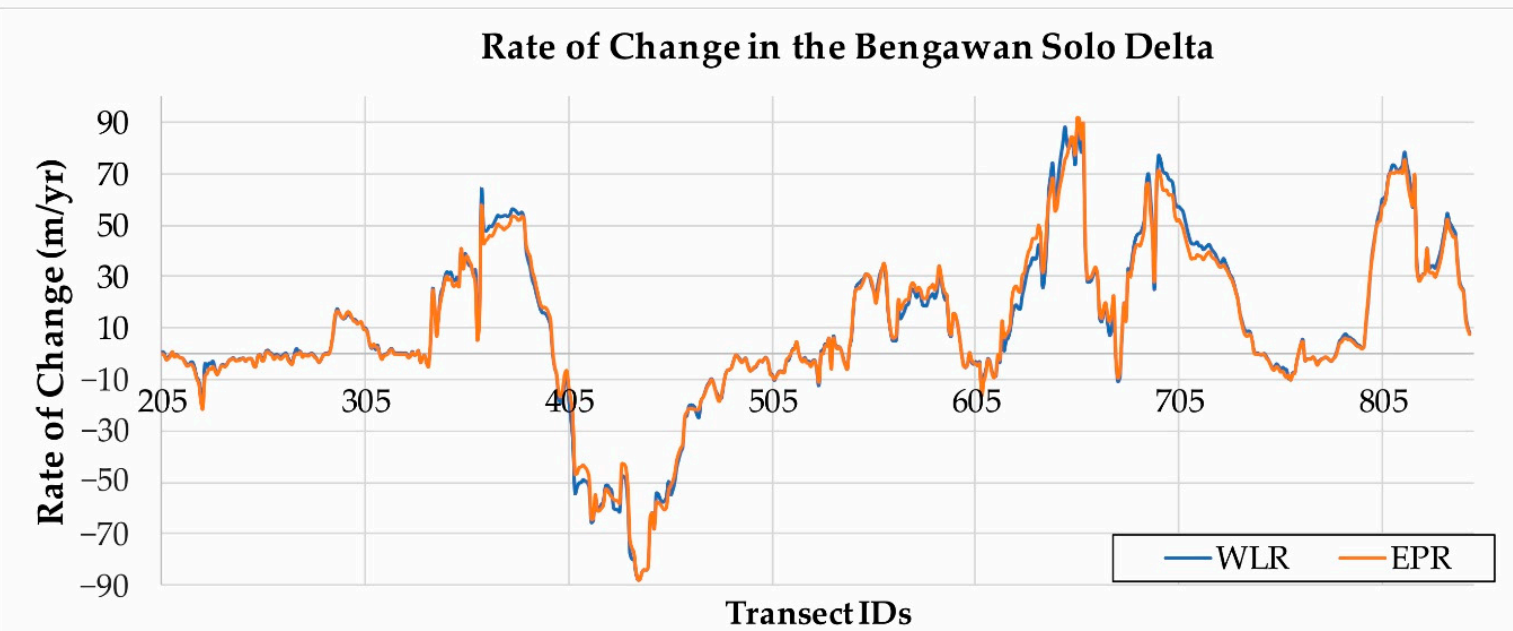

Figure 7. Rate of change in the delta of the Bengawan Solo river from 2000 to 2019, displaying both major accretion and erosion, in the range of +89.65 to $-87.44 \mathrm{~m} /$ year (EPR).

For the Brantas/Porong delta region (Figure 6B), we found an average shoreline change of $+13.28 \mathrm{~m} /$ year from 2000 to 2019 . The rate of shoreline change ranged from -19.98 to $+111.75 \mathrm{~m} /$ year (EPR) (Figure 8). Unlike the Bengawan Solo delta, the Brantas/Porong delta showed no erosion at rates of more than $\sim 20 \mathrm{~m} /$ year. The land-cover composition in the Brantas/Porong delta is similar to that in the Bengawan Solo delta; the acquired land is used for aquaculture ponds and as mangrove conservation areas. The massive coastal sedimentation in the delta of the Brantas/Porong river is due to a mud volcano explosion in May 2006. During this event, underground mud was lifted to the surface, carried by the river, and deposited in the delta, adding around 3,881.8 ha of additional land to the area [63].

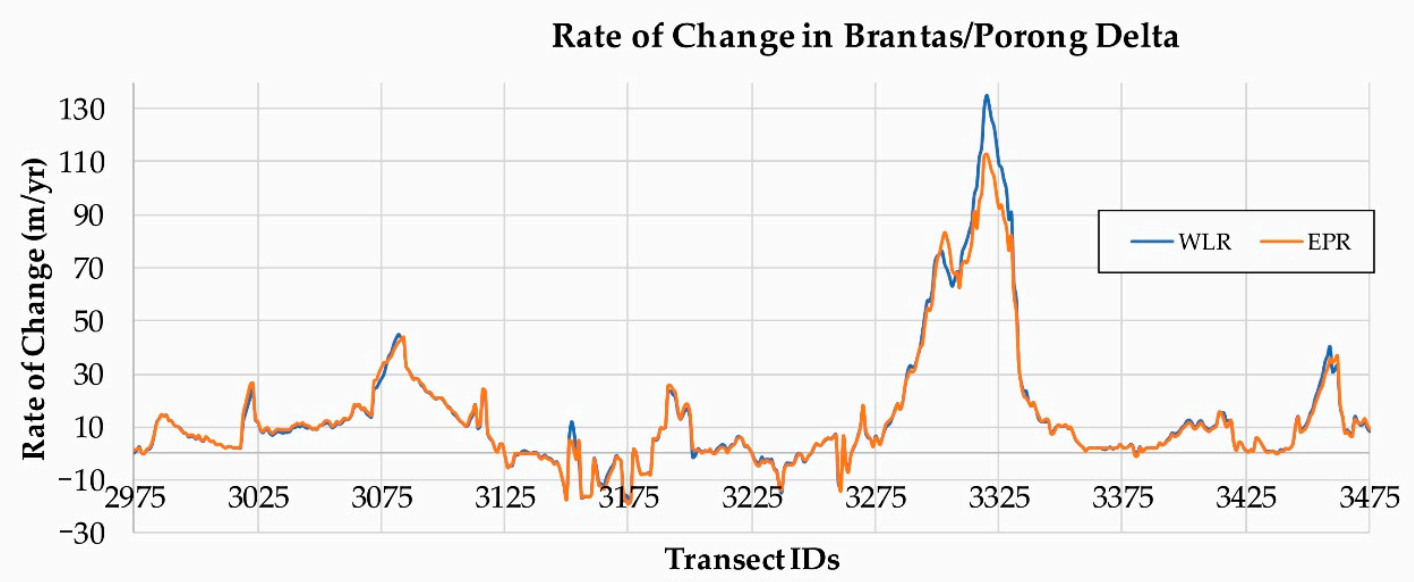

Figure 8. Rate of change in the delta of the Brantas/Porong river from 2000 to 2019, displaying major accretion (up to $+111.75 \mathrm{~m} /$ year) and moderate erosion (up to $-18.98 \mathrm{~m} /$ year) (EPR). 


\subsection{Land Use of the Accretion and Erosion Areas in the Coastal Regions in 2000 to 2019}

The mapped land-use classes in the Bengawan Solo and Brantas/Porong deltas can be found in Figure 9. Most of the delta regions were used as mangrove and aquaculture areas, especially in the Brantas/Porong delta. In contrast, in the Bengawan Solo delta, small portions of the areas were used as plantation and built-up areas. Based on the land-use classification results and the shoreline changes in 2000 and 2019, the mangrove and aquaculture areas were the main affected land-use classes in those deltas.
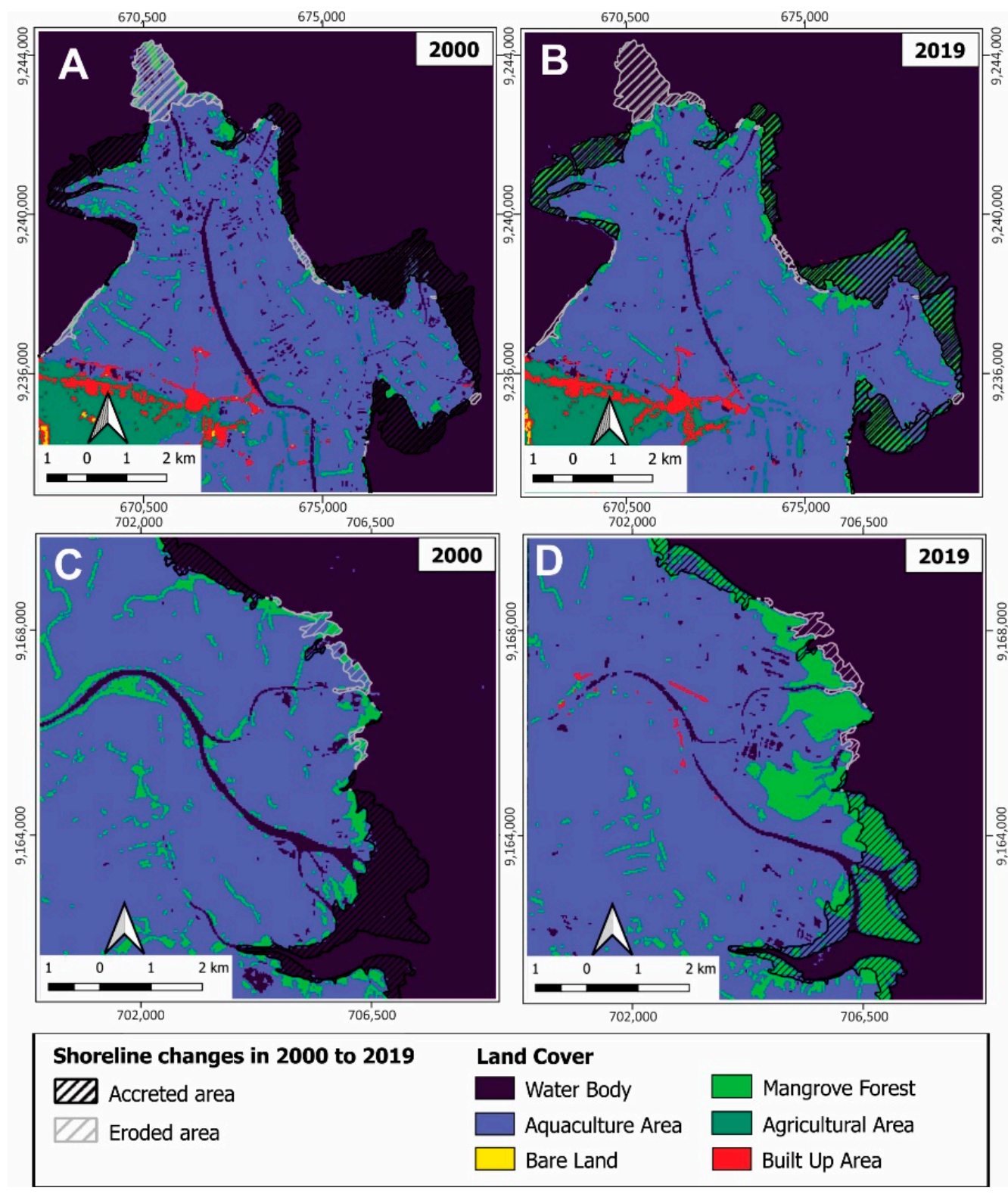

Figure 9. Land-use composition and shoreline changes from 2000 to 2019 in the Bengawan Solo river in (A) 2000 and (B) 2019 and in the Brantas/Porong river in (C) 2000 and (D) 2019.

Based on the overlay results between the shoreline changes and the land-use information in 2000 and 2019, the type of land use that was developed in the accreted areas and lost in the eroded areas is summarized in Table 3. In the Bengawan Solo delta, around 176.59 ha of aquaculture and 40.05 ha of mangrove areas were lost because of coastal erosion; however, around 471.50 ha of aquaculture and 413.44 ha of mangrove areas were developed in the accreted areas. Similar land-use composition for the eroded and accreted areas was also found in the Brantas/Porong delta. Most of the accreted areas were used 
for mangrove plantations, with 251.85 ha along the shoreline of the Brantas/Porong delta, and for aquaculture, with 166.97 ha. The coastal erosion in the Brantas/Porong delta was notably lower, with only 57.4 ha, which happened mostly in the aquaculture areas.

Table 3. Summary of major land use in 2000 and 2019 in the coastal accreted and eroded areas.

\begin{tabular}{cccc}
\hline \multirow{2}{*}{ Delta } & Type of Coastal Land & Type of Land Use & Area (ha) \\
\hline \multirow{3}{*}{ Bengawan Solo } & Accreted area in 2019 & Mangrove & 413.44 \\
& & Aquaculture & 471.50 \\
\cline { 2 - 4 } & Eroded area in 2019 & Mangrove & 40.05 \\
& & Aquaculture & 176.59 \\
\hline \multirow{3}{*}{ Brantas/Porong } & Accreted area in 2019 & Mangrove & 251.85 \\
\cline { 2 - 4 } & & Aquaculture & 166.97 \\
& Eroded area in 2019 & Mangrove & 15.96 \\
& & Aquaculture & 41.44 \\
\hline
\end{tabular}

\section{Discussion}

\subsection{Detecting Shorelines from Satellite Imagery Data}

Various methods are available for detecting and monitoring shoreline changes from satellite imagery. These methods rely on the ability of the satellite imagery to discriminate between land and water bodies, which is commonly achieved by using (1) the histogram threshold value from water indices, such as the infrared band ratio [64] and the modified NDWI and AWEI [65,66], or (2) supervised classification [67,68]. Although histogram thresholding methods are far simpler than supervised classification, the threshold must be chosen carefully to avoid further classification noise [65]. The applicability of the histogram thresholding method to composite data of annual medians, such as the remote sensing data that we used in our study, would require further assessment. The AWEI is thought to be the most consistent index for separating land and seawater compared with the modified NDWI [65]. The assessment of which method to use should be made based on the selection of the appropriate spectral indices and threshold values, since the pixel values are taken from different dates within a year of data. In addition, the performance of each index may vary depending on the type of coast [69]. A problem with the histogram thresholding method was the rationale behind the use of supervised classification as the main method for detecting shorelines in our analysis. The use of the GEE platform in our analysis enabled the access of multi-sensor medium-resolution satellite datasets, which were useful for the purpose of classifying with greater accuracy and over a wider area of analysis.

The GMO-Maxent classification results were used in this study because of their greater accuracy when compared with RF classification, especially for the years when only Landsat data were available (e.g., 2000, 2005, and 2010). The RF method was able to provide slightly better accuracies when more data were used as input for the classification, such as the Sentinel-1 radar data for the years 2015 and 2019. Although several studies, such as the work of Farda [70], have asserted the superiority of RF as compared with GMO-Maxent, RF requires fine-tuning to optimize classification, which runs the risk of reduced accuracy, as shown in the study by Shelestov et al. [71], in which the accuracy of RF was lower than that of GMO-Maxent. Nonetheless, it should be noted that the final results of GMO-Maxent still require manual refining to obtain the most accurate shoreline results possible and to ensure the correct calculation of shoreline changes from the classification results.

\subsection{Shoreline and Land-Use Changes from 2000 to 2019}

The shorelines of the examined portion of East Java Province displayed a high degree of dynamism between 2000 and 2019, with an overall trend of accretion along the shoreline. Examination of the data led to the identification of two major areas of shoreline changes, namely the Brantas/Porong and Bengawan Solo deltas. In the Brantas/Porong delta, accretion was dominant, which can be attributed to sediments from the mud volcano 
disaster in Sidoarjo, which directed sediments to the Brantas/Porong river. During the wet periods, floods and water flows gradually flushed significant amounts of mud into the Brantas/Porong delta from the mud volcano event during the dry period [72]. Kure, Winarta, Takeda, Udo, Umeda, Mano, and Tanaka [72] also found twice the normal amount of suspended matter and particulate organic carbon in the Porong river as a result of the mud volcano event. Our study showed the gradual accretion of the Brantas/Porong delta from 2000 to 2019. However, the exact influence of the mud volcano sediments on the shoreline changes still requires further assessment, as accretion and erosion of the shoreline may also be influenced by ocean wave patterns. Nonetheless, Wijayanti [73] indicated that there was a correlation between the amount of suspended matter and the coastline changes in the Brantas/Porong delta.

The second area that showed massive changes was the Bengawan Solo delta. Although accretion dominated in this area, with an average rate of change of $+10.2 \mathrm{~m} /$ year, some parts of the delta also suffered from massive coastal erosion, with a maximum rate of $-87.44 \mathrm{~m}$ /year. Our results complement previous analyses, which identified erosion only in the western part of the delta from 1972 to 2016, albeit at a much slower rate $(-5.54 \mathrm{~m} /$ year) [29]. Although our study found some major coastal erosion in the Bengawan Solo delta, this was not the case during the late 1980s. Hoekstra [74] identified the Bengawan Solo and Brantas/Porong deltas as rapidly growing deltas, which received substantial quantities of sediments, transported during the wet seasons from 1890 to 1985. The Bengawan Solo delta was formed by a single river channel, with a growth of $+70 \mathrm{~m} /$ year [75], a figure that drastically dropped to $+10.2 \mathrm{~m} /$ year from 2000 to 2019 .

Although the observed massive coastal erosion occurred in non-urban areas, the shoreline dynamics in this area evidently require proper monitoring to avoid potential hazards in the future and to best manage the accreted land. Here, the major accretion and erosion occurred in less populated regions of the deltas, reducing the risk to society; however, coastal erosion occurred in areas of aquaculture land use, which could pose an economic problem to local communities that depend on aquaculture production [76] or which may produce a conflict in the management of the accreted lands. To minimize the socioeconomic impact of coastal erosion, coastal defense mechanisms supported by integrated coastal management should be implemented. In Indonesia, afforestation by planting mangrove in the accreted areas is the common procedure for coastal land management [77]. However, controlling accretion may be more important, especially if an offshore reef ecosystem is present, since terrestrial sediments reduce the water quality and increase the turbidity, which in turn limits the resources needed by coral reefs to grow [78]. Therefore, the detection of regional-level shoreline dynamics can be utilized to identify vulnerable coral reef ecosystems and mitigate the negative impact of ongoing sedimentation.

In addition, our results can also be used to create a measure or index for quantifying the coastal vulnerability risks by employing the direction and trend of shoreline changes to identify the elements that are at risk of shoreline changes. The coastal risk index (CRI-Med), developed by Satta et al. [79], and the coastal vulnerability index (CVI), developed by Gornitz et al. [80], use sea level rise, drought, and wave height as the hazard components and tourism, population, and land use as the elements at risk. The elements at risk, i.e., land use and population, can be identified, and the vulnerability can be calculated by looking at the trend of shoreline changes and the distance of the erosion sites to the population or the land-use areas.

\section{Conclusions}

Our study demonstrated the use of cloud computing-employing the GEE, multisensor and multi-temporal satellite imagery, supervised classification, and GIS analysis, as well as DSAS-in monitoring the shoreline dynamics from 2000 to 2019 of a large part of East Java Province, Indonesia. In our study, we found that GMO-Maxent methods can give relatively stable, high accuracies ( $84 \%$ to $95.2 \%$ ) when compared with RF methods, especially when only Landsat data were used. The manually refined shoreline generated by the 
GMO-Maxent method showed general accretion, at rates of +4.12 (EPR) and $+4.26 \mathrm{~m} /$ year (WLR). Massive changes were found in two deltas: the Brantas/Porong delta, which underwent major accretion, and the Bengawan Solo delta, which experienced both major accretion and major erosion. Most of the land areas derived from shoreline changes, such as accretion zones, were converted into mangrove and aquaculture areas, replacing the same land-use type that disappeared because of coastal erosion. The shoreline dynamics in this area require proper monitoring to ensure the maximal environmental benefit from the accreted areas and to avoid the risk of environmental hazards and socioeconomic problems due to coastal erosion.

Supplementary Materials: The following are available online at https://www.mdpi.com/2073-445 X/10/2/100/s1: S1: Code to run the classification in Google Earth Engine.

Author Contributions: Conceptualization, S.A., P.W., B.W.M.; methodology, S.A.; software, S.S.K., S.S.; formal analysis, S.A.; preparation of the original draft, S.A.; reviewing and editing of the manuscript, S.A., P.W., B.W.M.; visualization, R.R., S.S.K.; supervision, P.W. All authors have read and agreed to the published version of the manuscript.

Funding: This research was funded by a grant of Basic Research for University (PDUPT) from the Directorate of Research and Community Service, Directorate General of Research and Development Strengthening Ministry of Research, and Technology and Higher Education of the Republic of Indonesia (Direktorat Riset dan Pengabdian Masyarakat, Direktorat Jenderal Penguatan Riset dan Pengembangan Kementerian Riset, Teknologi dan Pendidikan Tinggi Republik Indonesia) with the grant number of 1677/UN1/DITLIT/DIT-LIT/PT/2020.

Institutional Review Board Statement: Not applicable.

Informed Consent Statement: Not applicable.

Data Availability Statement: Not applicable.

Acknowledgments: We thank anonymous reviewers for constructive comments on the manuscript, Google for providing the cloud computing platform of the GEE, and the data providers for the GEE (USGS, JAXA, and the European Space Agency).

Conflicts of Interest: The authors declare no conflict of interest.

\section{References}

1. Erlandson, J.M. Racing a rising tide: Global warming, rising seas, and the erosion of human history. J. Isl. Coast. Archeol. 2008, 3, 167-169. [CrossRef]

2. Church, J.A.; White, N.J. A 20th century acceleration in global sea-level rise. Geophys. Res. Lett. 2006, 33. [CrossRef]

3. Rahmstorf, S. A semi-empirical approach to projecting future sea-level rise. Science 2007, 315, 368-370. [CrossRef] [PubMed]

4. Nicholls, R.J.; Cazenave, A. Sea-level rise and its impact on coastal zones. Science 2010, 328, 1517-1520. [CrossRef] [PubMed]

5. Shepherd, A.; Ivins, E.R.; Geruo, A.; Barletta, V.R.; Bentley, M.J.; Bettadpur, S.; Briggs, K.H.; Bromwich, D.H.; Forsberg, R.; Galin, N. A reconciled estimate of ice-sheet mass balance. Science 2012, 338, 1183-1189. [CrossRef] [PubMed]

6. Everts, C.H. Sea level rise effects on shoreline position. J. Waterw. Port. Coast. Ocean Eng. 1985, 111, 985-999. [CrossRef]

7. Cazenave, A.; Cozannet, G.L. Sea level rise and its coastal impacts. Earth's Future 2014, 2, 15-34. [CrossRef]

8. Leatherman, S.P.; Zhang, K.; Douglas, B.C. Sea level rise shown to drive coastal erosion. Trans. Am. Geophys. Union 2000, 81, 55-57. [CrossRef]

9. Zhang, K.; Douglas, B.C.; Leatherman, S.P. Global warming and coastal erosion. Clim. Chang. 2004, 64, 41. [CrossRef]

10. Mutaqin, B.W. Shoreline changes analysis in kuwaru coastal area, Yogyakarta, Indonesia: An application of the digital shoreline analysis system (DSAS). Int. J. Sustain. Dev. Plan. 2017, 12, 1203-1214. [CrossRef]

11. Ji, T.; Li, G. Contemporary monitoring of storm surge activity. Prog. Phys. Geogr. Earth Environ. 2020, 44, 299-314. [CrossRef]

12. Lionello, P.; Cavaleri, L.; Nissen, K.M.; Pino, C.; Raicich, F.; Ulbrich, U. Severe marine storms in the Northern Adriatic: Characteristics and trends. Phys. Chem. Earth 2012, 40-41, 93-105. [CrossRef]

13. Temmerman, S.; Meire, P.; Bouma, T.J.; Herman, P.M.J.; Ysebaert, T.; De Vriend, H.J. Ecosystem-based coastal defence in the face of global change. Nature 2013, 504, 79-83. [CrossRef] [PubMed]

14. Mentaschi, L.; Vousdoukas, M.I.; Pekel, J.-F.; Voukouvalas, E.; Feyen, L. Global long-term observations of coastal erosion and accretion. Sci. Rep. 2018, 8, 1-11. [CrossRef] [PubMed]

15. Leatherman, S.P.; Douglas, B.C.; LaBrecque, J.L. Sea level and coastal erosion require large-scale monitoring. Trans. Am. Geophys. Union 2003, 84, 13-16. [CrossRef] 
16. Ingebritsen, S.E.; Galloway, D.L. Coastal subsidence and relative sea level rise. Environ. Res. Lett. 2014, 9, 091002. [CrossRef]

17. Williams, S.J. Sea-level rise implications for coastal regions. J. Coast. Res. 2013, 184-196. [CrossRef]

18. Stive, M.J. How important is global warming for coastal erosion? Clim. Chang. 2004, 64, 27. [CrossRef]

19. Marfai, M.A. The hazards of coastal erosion in Central Java, Indonesia: An overview. Geogr. Malays. J. Soc. Space 2017, 7, 1-9.

20. Marfai, M.A.; King, L. Coastal flood management in Semarang, Indonesia. Environ. Geol. 2008, 55, 1507-1518. [CrossRef]

21. Salim, W.; Kombaitan, B.J.C. Jakarta: The rise and challenge of a capital. City 2009, 13, 120-128. [CrossRef]

22. Martins, G.M.; Amaral, A.F.; Wallenstein, F.M.; Neto, A.I. Influence of a breakwater on nearby rocky intertidal community structure. Mar. Environ. Res. 2009, 67, 237-245. [CrossRef] [PubMed]

23. Maiolo, M.; Mel, R.A.; Sinopoli, S. A Stepwise Approach to Beach Restoration at Calabaia Beach. Water 2020, 12, 2677. [CrossRef]

24. Ye, G.; Chou, L.M.; Yang, S.; Wu, J.; Liu, P.; Jin, C. Is integrated coastal management an effective framework for promoting coastal sustainability in China's coastal cities? Mar. Policy 2015, 56, 48-55. [CrossRef]

25. Turner, R.K. Integrating natural and socio-economic science in coastal management. J. Mar. Syst. 2000, 25, 447-460. [CrossRef]

26. Marfai, M.A.; Almohammad, H.; Dey, S.; Susanto, B.; King, L. Coastal dynamic and shoreline mapping: Multi-sources spatial data analysis in Semarang Indonesia. Environ. Monit. Assess. 2008, 142, 297-308. [CrossRef]

27. Libriyono, A.; Kusratmoko, E.; Kertopermono, A.P. Spatial modelling of shoreline change to coastal disaster management in Jakarta Bay. AIP Conf. Proc. 2018, 1987, 020021.

28. Chairani, C.; Saraswati, R.; Shidiq, I. Identification of changes mangrove areas toward shoreline changes in East Coast of Surabaya 2004-2017. In Proceedings of the IOP Conference Series: Earth and Environmental Science, Bandung, Indonesia, 2-4 July 2018; p. 012002.

29. Fuad, M.; Fais, D. Automatic Detection of Decadal Shoreline Change on Northern Coastal of Gresik, East Java-Indonesia. In Proceedings of the IOP Conference Series: Earth and Environmental Science, Yogyakarta, Indonesia, 27-28 September 2017.

30. Dewi, R.S.; Bijker, W.; Stein, A.; Marfai, M.A. Fuzzy classification for shoreline change monitoring in a part of the northern coastal area of Java, Indonesia. Remote Sens. 2016, 8, 190. [CrossRef]

31. Blodget, H.; Taylor, P.; Roark, J. Shoreline changes along the Rosetta-Nile Promontory: Monitoring with satellite observations. Mar. Geol. 1991, 99, 67-77. [CrossRef]

32. Kuleli, T. Quantitative analysis of shoreline changes at the Mediterranean Coast in Turkey. Environ. Monit. Assess. 2010, 167, 387-397. [CrossRef]

33. Tamassoki, E.; Amiri, H.; Soleymani, Z. Monitoring of shoreline changes using remote sensing (case study: Coastal city of Bandar Abbas). In Proceedings of the IOP Conference Series: Earth and Environmental Science, Kuala Lumpur, Malaysia, 22-23 April 2014; p. 012023.

34. Thi, V.T.; Xuan, A.T.T.; Nguyen, H.P.; Dahdouh-Guebas, F.; Koedam, N. Application of remote sensing and GIS for detection of long-term mangrove shoreline changes in Mui Ca Mau, Vietnam. Biogeosciences 2014, 11, 3781.

35. M-Muslim, A.; Foody, G.M.; Atkinson, P.M. Shoreline mapping from coarse-spatial resolution remote sensing imagery of Seberang Takir, Malaysia. J. Coast. Res. 2007, 23, 1399-1408. [CrossRef]

36. Gorelick, N.; Hancher, M.; Dixon, M.; Ilyushchenko, S.; Thau, D.; Moore, R. Google Earth Engine: Planetary-scale geospatial analysis for everyone. Remote Sens. Environ. 2017, 202, 18-27. [CrossRef]

37. Chu, L.; Oloo, F.; Sudmanns, M.; Tiede, D.; Hölbling, D.; Blaschke, T.; Teleoaca, I. Monitoring long-term shoreline dynamics and human activities in the Hangzhou Bay, China, combining daytime and nighttime EO data. Big Earth Data 2020, 4, 1-23. [CrossRef]

38. Vos, K.; Harley, M.D.; Splinter, K.D.; Simmons, J.A.; Turner, I.L. Sub-annual to multi-decadal shoreline variability from publicly available satellite imagery. Coast. Eng. 2019, 150, 160-174. [CrossRef]

39. Propp, C.; Jänen, I.; Jennerjahn, T. Sources and degradation of sedimentary organic matter in coastal waters off the Brantas River, Java, Indonesia. Asian J. Water Environ. Pollut. 2013, 10, 95-115.

40. Lebreton, L.C.; Van Der Zwet, J.; Damsteeg, J.-W.; Slat, B.; Andrady, A.; Reisser, J. River plastic emissions to the world's oceans. Nat. Commun. 2017, 8, 15611. [CrossRef]

41. Lestari, P.; Trihadiningrum, Y.; Wijaya, B.A.; Yunus, K.A.; Firdaus, M. Distribution of microplastics in Surabaya River, Indonesia. Sci. Total Environ. 2020, 726, 138560. [CrossRef]

42. Lestari, P.; Trihadiningrum, Y. The impact of improper solid waste management to plastic pollution in Indonesian coast and marine environment. Mar. Pollut. Bull. 2019, 149, 110505. [CrossRef]

43. Wang, Y.C.; Feng, C.C.; Vu Duc, H. Integrating Multi-Sensor Remote Sensing Data for Land Use/Cover Mapping in a Tropical Mountainous Area in Northern Thailand. Geogr. Res. 2012, 50, 320-331. [CrossRef]

44. Töyrä, J.; Pietroniro, A.; Martz, L.W.; Prowse, T.D. A multi-sensor approach to wetland flood monitoring. Hydrol. Process. 2002, 16, 1569-1581. [CrossRef]

45. Taha, L.G.E.-d.; Elbeih, S.F. Investigation of fusion of SAR and Landsat data for shoreline super resolution mapping: The northeastern Mediterranean Sea coast in Egypt. Appl. Geomat. 2010, 2, 177-186. [CrossRef]

46. McFeeters, S.K. The use of the Normalized Difference Water Index (NDWI) in the delineation of open water features. Int. J. Remote Sens. 1996, 17, 1425-1432. [CrossRef]

47. JW, R.; Haas, R.; Schell, J.; Deering, D. Monitoring vegetation systems in the Great Plains with ERTS. In Proceedings of the Third Earth Resources Technology Satellite-1 Symposium, Washington, DC, USA, 10-14 December 1973; Volume 1, pp. $309-317$. 
48. Feyisa, G.L.; Meilby, H.; Fensholt, R.; Proud, S.R. Automated Water Extraction Index: A new technique for surface water mapping using Landsat imagery. Remote Sens. Environ. 2014, 140, 23-35. [CrossRef]

49. Mcdonald, R.; Mohri, M.; Silberman, N.; Walker, D.; Mann, G.S. Efficient large-scale distributed training of conditional maximum entropy models. Adv. Neural Inf. Process. Syst. 2009, 22, 1231-1239.

50. Segal, I.E. A note on the concept of entropy. J. Math. Mech. 1948, 27, 379-423. [CrossRef]

51. Vajapeyam, S. Understanding Shannon's Entropy metric for Information. arXiv 2014, arXiv:1405.2061.

52. Jaynes, E.T. Information theory and statistical mechanics. Phys. Rev. 1957, 106, 620. [CrossRef]

53. Phillips, S.J.; Anderson, R.P.; Schapire, R.E. Maximum entropy modeling of species geographic distributions. Ecol. Model. 2006, 190, 231-259. [CrossRef]

54. Phillips, S.J.; Dudík, M.; Schapire, R.E. A maximum entropy approach to species distribution modeling. In Proceedings of the Twenty-First International Conference on Machine Learning, Banff, Alberta, 4-8 July 2004; p. 83.

55. Ahmed, N.; Islam, M.N.; Hasan, M.F.; Motahar, T.; Sujauddin, M. Understanding the political ecology of forced migration and deforestation through a multi-algorithm classification approach: The case of Rohingya displacement in the southeastern border region of Bangladesh. Geol. Ecol. Landsc. 2019, 3, 282-294. [CrossRef]

56. Baldwin, R.A. Use of maximum entropy modeling in wildlife research. Entropy 2009, 11, 854-866. [CrossRef]

57. Kumar, S.; Stohlgren, T.J. Maxent modeling for predicting suitable habitat for threatened and endangered tree Canacomyrica monticola in New Caledonia. J. Ecol. Nat. Environ. 2009, 1, 094-098.

58. Li, W.; Guo, Q. A maximum entropy approach to one-class classification of remote sensing imagery. Int. J. Remote Sens. 2010, 31, 2227-2235. [CrossRef]

59. Breiman, L. Random forests. Mach. Learn. 2001, 45, 5-32. [CrossRef]

60. Himmelstoss, E.A.; Henderson, R.E.; Kratzmann, M.G.; Farris, A.S. Digital Shoreline Analysis System (DSAS) Version 5.0 User Guide; US Geological Survey: Reston, VA, USA, 2018; pp. 1258-2331.

61. Baig, M.R.I.; Ahmad, I.A.; Shahfahad; Tayyab, M.; Rahman, A. Analysis of shoreline changes in Vishakhapatnam coastal tract of Andhra Pradesh, India: An application of digital shoreline analysis system (DSAS). Ann. Gis. 2020, 26, 361-376. [CrossRef]

62. Thinh, N.A.; Hens, L. A Digital Shoreline Analysis System (DSAS) applied on mangrove shoreline changes along the Giao Thuy coastal area (Nam Dinh, Vietnam) during 2005-2014. Vietnam J. Earth Sci. 2017, 39, 87-96. [CrossRef]

63. Maryantika, N.; Lin, C. Exploring changes of land use and mangrove distribution in the economic area of Sidoarjo District, East Java using multi-temporal Landsat images. Inf. Process. Agric. 2017, 4, 321-332. [CrossRef]

64. Alesheikh, A.A.; Ghorbanali, A.; Nouri, N. Coastline change detection using remote sensing. Int. J. Environ. Sci. Technol. 2007, 4, 61-66. [CrossRef]

65. Sunder, S.; Ramsankaran, R.; Ramakrishnan, B. Inter-comparison of remote sensing sensing-based shoreline mapping techniques at different coastal stretches of India. Environ. Monit. Assess. 2017, 189, 290. [CrossRef]

66. Kelly, J.T.; Gontz, A.M. Using GPS-surveyed intertidal zones to determine the validity of shorelines automatically mapped by Landsat water indices. Int. J. Appl. Earth Obs. Geoinf. 2018, 65, 92-104. [CrossRef]

67. Masria, A.; Nadaoka, K.; Negm, A.; Iskander, M.J.L. Detection of shoreline and land cover changes around Rosetta promontory, Egypt, based on remote sensing analysis. Land 2015, 4, 216-230. [CrossRef]

68. Sekovski, I.; Stecchi, F.; Mancini, F.; Del Rio, L. Image classification methods applied to shoreline extraction on very high-resolution multispectral imagery. Int. J. Remote Sens. 2014, 35, 3556-3578. [CrossRef]

69. Wicaksono, A.; Wicaksono, P. Geometric Accuracy Assessment for Shoreline Derived from NDWI, MNDWI, and AWEI Transformation on Various Coastal Physical Typology in Jepara Regency using Landsat 8 OLI Imagery in 2018. Geoplanning J. Geomat. Plan. 2019, 6, 55-72. [CrossRef]

70. Farda, N. Multi-temporal land use mapping of coastal wetlands area using machine learning in Google earth engine. In Proceedings of the IOP Conference Series: Earth and Environmental Science, Yogyakarta, Indonesia, 27-28 September 2017; p. 012042.

71. Shelestov, A.; Lavreniuk, M.; Kussul, N.; Novikov, A.; Skakun, S. Exploring Google Earth Engine platform for big data processing: Classification of multi-temporal satellite imagery for crop mapping. Front. Earth Sci. 2017, 5, 17. [CrossRef]

72. Kure, S.; Winarta, B.; Takeda, Y.; Udo, K.; Umeda, M.; Mano, A.; Tanaka, H. Effects of mud flows from the LUSI mud volcano on the Porong River estuary, Indonesia. J. Coast. Res. 2014, 568-573. [CrossRef]

73. Wijayanti, N.D. Pemetaan distribusi total suspended solid dan perubahan garis pantai di sidoarjo-pasuruan dengan menggunakan data penginderaan jauh. Geomatika 2020, 26, 25-34. [CrossRef]

74. Hoekstra, P. The development of two major Indonesian river deltas: Morphology and sedimentary aspects of the Solo and Porong delta, East Java. In Coastal Lowlands; Springer: Dordrecht, The Netherlands, 1989; pp. 143-159.

75. Hoekstra, P.; Tiktanaka. Coastal hydrodynamics, geomorphology and sedimentary environments of two major Javanese river deltas. Program and preliminary results from the Snellius-II expedition (Indonesia). J. Southeast Asian Earth Sci. 1988, 2, 95-107. [CrossRef]

76. Van Wesenbeeck, B.; Balke, T.; Van Eijk, P.; Tonneijck, F.; Siry, H.; Rudianto, M.; Winterwerp, J. Aquaculture induced erosion of tropical coastlines throws coastal communities back into poverty. Ocean Coast. Manag. 2015, 116, 466-469. [CrossRef]

77. Dharmawan, B.; Böcher, M.; Krott, M. Endangered mangroves in Segara Anakan, Indonesia: Effective and failed problem-solving policy advice. Environ. Manag. 2017, 60, 409-421. [CrossRef] 
78. Perry, C.T.; Smithers, S.G.; Gulliver, P.; Browne, N.K. Evidence of very rapid reef accretion and reef growth under high turbidity and terrigenous sedimentation. Geology 2012, 40, 719-722. [CrossRef]

79. Satta, A.; Puddu, M.; Venturini, S.; Giupponi, C. Assessment of coastal risks to climate change related impacts at the regional scale: The case of the Mediterranean region. Int. J. Disaster Risk Reduct. 2017, 24, 284-296. [CrossRef]

80. Gornitz, V.M.; Daniels, R.C.; White, T.W.; Birdwell, K.R. The development of a coastal risk assessment database: Vulnerability to sea-level rise in the US Southeast. J. Coast. Res. 1994, 12, 327-338. 